Instytutu Prahistorii, studenci wszystkich lat studiów licencjackich i magisterskich, doktoranci oraz absolwenci poznańskiej archeologii. Podstawowym celem było zwiedzenie najważniejszych stanowisk archeologicznych położonych w północno-wschdniej części Półwyspu Iberyjskiego oraz reprezentatywnych dla archeologii śródziemnomorskiej kolekcji muzealnych. Poza miejscowościami odwiedzonymi w trakcie dwudniowej drogi na Półwysep Iberyjski, w samej Hiszpanii uczestnicy zwiedzili rzymskie zabytki w Barcelonie: świątynię Augusta, mury miejskie, pozostałości po akweduktach, nekropolę, a także Muzeum Archeologii Katalonii. Spośród odwiedzonych stanowisk archeologicznych najważniejsze były: osada iberyjska w Ullastret, kolonia grecka i miasto rzymskie w Ampurias, dolmen w Romanya de la Selva, akwedukt „Pont del Diable”, willa rzymska w Altafulla, a także oppidum w Ensérune. Uczestnicy objazdu zwiedzili również Muzeum Archeologiczne w Geronie oraz rzymskie i wczesnochrześcijańskie zabytki Tarragony, takie jak mury miejskie, amfiteatr, pozostałości forum wraz z Muzeum Archeologicznym. Na temat wszystkich zabytków studenci II roku sporządzili referaty omawiające historię, stan badań i znaczenie wybranych przez siebie obiektów. Po powrocie do Polski przygotowali również plakat przedstawiający pokonaną trasę i odwiedzone zabytki.

Objazd nie doszedłby do skutku, gdyby nie wsparcie władz Uniwersytetu: dofinansowanie Pana Prorektora ds. Studenckich, Pana Dziekana Wydziału Historycznego i Pani Dyrektor Instytutu Prahistorii obniżyło o ponad 1/3 koszty uczestnictwa studentów II roku w przedsięwzięciu. Dla osób, które z różnych powodów nie mogły pojechać do Hiszpanii, w dniach 17-18 kwietnia 2013 r. zorganizowany został objazd po zabytkach i muzeach Kujaw oraz Wielkopolski (Gołuchów, Kalisz, Giecz, Biskupin, Strzelno, Kruszwica, Gniezno, Ostrów Lednicki), z finansowym wsparciem Pani Dyrektor Instytutu Prahistorii oraz szczególnym zaangażowaniem dr Katarzyny Pyżewicz i dr. Artura Różańskiego, a także dr Mileny Teski, dr. Michała Pawlety i niżej podpisanego.

Michat Krueger

Instytut Prahistorii, Uniwersytet im. A. Mickiewicza

ul. Św. Marcin 78, 61-809 Poznań, Poland

\title{
JUBILEUSZOWA MIECDZYNARODOWA ARCHEOLOGICZNA KONFERENCJA NAUKOWA WE LWOWIE (22-24 MAJA 2013 R., LWÓW, UKRAINA)
}

Archeologia jako nauka ma długą tradycję na zachodniej Ukrainie, a Lwów jest największym po Kijowie ośrodkiem dydaktyczno-badawczym. Obok archeologii uniwersyteckiej działa tu Instytut Ukrainoznawstwa im. Iwana Krypjakevyča Narodowej Akademii Nauk Ukrainy. To on właśnie organizuje coroczne międzynarodowe konferencje „Archeologia Zachodu Ukrainy".

Niemal sto referatów zgłoszonych do programu konferencji, ponad 120 archeologów i historyków z Białorusi, Polski, Rosji, Słowacji i różnych regionów Ukrainy - tak zaprezen- 
towało się środowisko naukowe na tegorocznej, jubileuszowej, dziesiątej Międzynarodowej Konferencji Naukowej „Archeologia Zachodu Ukrainy”, która odbyła się we Lwowie w dniach 22-24 maja $2013 \mathrm{r}$.

Liczba uczestników i wygłoszonych referatów była tak duża, że wystąpienia - po raz pierwszy - odbywały się w ramach sesji plenarnej oraz dwóch sekcji: „Archeologii pradziejowej” i „Archeologii średniowiecza i nowożytności”. W każdej z wymienionych sekcji referaty wygłaszano podczas sesji porannej i wieczornej. Posiedzenia odbywały się w siedzibie Instytutu Ukrainoznawstwa - w auli Naukowego Towarzystwa im. T. Szewczenki oraz w Muzeum Archeologicznym.

Otwierając konferencję, dyrektor Instytutu Ukrainoznawstwa im. Krypjakevyča Narodowej Akademii Nauk Ukrainy, prof. dr hab. Mykoła Łytwyn, wygłosił powitalne przemówienie do uczestników i gości. Podkreślił, że wśród miejscowych archeologów istnieje dobry zwyczaj spotykania się na sympozjach naukowych. Znaczący jest także fakt, że zainteresowanie środowiska archeologów corocznymi konferencjami nie zmniejsza się, a wręcz przeciwnie - rośnie z roku na rok. Potwierdza to ich wysoką rangę, a także znaczenie Lwowa jako ośrodka archeologii w regionie i w tej części Europy Środkowo-Wschodniej.

Posiedzenie plenarne, którego poranna część odbywała się pod kierownictwem dyrektora Oddziału Archeologii Instytutu Ukrainoznawstwa, prof. dr. hab. Oleksandra Sytnyka, rozpoczęło się referatem samego prowadzącego: „Dziesięć lat konferencji «Archeologia Zachodu Ukrainy» we Lwowie”. Przedstawił on szczegółową analizę i „statystykę” przeprowadzonych dotąd spotkań, opowiedział o historii powstania konferencji, udziale archeologów z regionu w organizacji, reprezentacji badaczy i instytucji naukowych, tematyce i problematyce wygłoszonych referatów. Popularność i poziom naukowy lwowskiej konferencji rośnie, co świadczy o konieczności kontynuowania tej tradycji.

Referat N. Bułyk (Lwów) pt. „Karol Hadaczek - pierwszy profesor archeologii Uniwersytetu Lwowskiego (z okazji 140. rocznicy urodzin)" dotyczył analizy życiowej drogi i dorobku naukowego tego znanego archeologa.

A. Janenko (Kijów) w referacie „Muzea zachodniej Ukrainy w latach 1945-1946” na podstawie badań archiwum M.J. Rudyńskiego przedstawiła dzieje materiałów archiwalnych, wymianę literatury i eksponatów archeologicznych między muzeami regionu w pierwszych latach po wojnie.

G. Poplevko (Petersburg) w odczycie „Możliwości zastosowania badań eksperymentalno-traseologicznych w stosunku do źródeł archeologicznych”, na podstawie analizy narzędzi do obróbki skóry, drewna, mięsa, kamienia i kości, zaprezentowała możliwości wykorzystania metody traseologicznej w archeologii. Ten właśnie referat został wyróżniony w trakcie podsumowującej dyskusji przez prof. J. Machnika, który wskazał na konieczność i istotność zastosowania w archeologii metod zapożyczonych z nauk przyrodniczych i ścisłych.

O. Łozovskaja (Petersburg) w referacie „Strategia wykorzystania surowca drzewnego i rekonstrukcja paleokrajobrazu w późnym mezolicie w Europie Wschodniej” przedstawiła stanowiska, na których odkryto artefakty z drewna. Większość z nich jest usytuowana na północy Europy.

W odczycie W. Łozovskiego i A. Mazurkiewicza (Petersburg) pt. „Początki wczesnego neolitu w Europie Wschodniej” scharakteryzowano terytorium Ukrainy, Białorusi i europejskiej części Rosji. Przedstawiono także dotychczasowy dorobek archeologów w badaniach nad lokalizacją centrów wczesnej genezy ceramiki. 
Grupa autorów w składzie: P. Jarosz, J. Machnik, M. Mazurek, A. Szczepanek (Kraków) omówiła proces zasiedlenia lessowej Wysoczyzny Kańczuckiej w referacie „Osadnictwo późnoneolityczne i wczesnobrązowe w Mirocinie na stanowiskach 24 i 27, pow. Jarosław”. Przedstawiono w nim wyniki badań wykopaliskowych pochówków niszowych z wyposażeniem, które - wraz ze znaleziskami z pobliskich osad - dają wyobrażenie o charakterze osadnictwa w tym regionie.

K. Tunia i M. Przybyła (Kraków) w referacie „Typy grobowców megalitycznych grupy południowo-wschodniej kultury pucharów lejkowatych” zaprezentowali rezultaty badań archeologicznych, uzupełniających obraz obrządowości pogrzebowej tego ugrupowania. Interesująca była zwłaszcza rekonstrukcja monumentalnej architektury funeralnej (megaksylony).

Odczyt A. Rezepkina (Petersburg) „Kultura pucharów lejkowatych na północno-zachodnim Kaukazie" dotyczył domniemanych pochówków tej kultury, odkrytych po raz pierwszy w latach 70. ubiegłego wieku, które z powodu swojej odmienności nie wpisywały się w miejscowy trend rozwoju kulturowego. Odkryte w nich naczynia wykazują dalekie analogie formalne z niemieckimi wersjami tego ugrupowania, a zwłaszcza z kulturą bernburgską.

D. Król, J. Rogoziński, M. Rybicka i A. Sznajdrowska (Rzeszów) w referacie „Zagadnienie datowania cmentarzysk i grobowca megalitycznego z lessów podkarpackich" dokonali analizy artefaktów ze stanowisk Szczytna 6, Święte 11 i Skołoszów 7 oraz ich datowania.

Podczas wieczornej sesji posiedzenia plenarnego, której przewodniczył D. Pavliv, zaprezentowano 10 referatów.

B. Gediga (Wrocław) w odczycie „Sztuka situl jako źródło poznania” przedstawił specyfikę wytwarzania i zdobienia tego typu naczyń, udokumentowanych podczas wykopalisk na terenie Polski. Odczyt M. Bandrivskiego, L. Krušelnyckiej i M. Biły (Lwów) „Brązowe situle typu Hajdúböszörmény jako wyznacznik holihradskiej przynależności skarbów z górnego dorzecza Dniestru (na podstawie materiałów ze stanowisk Nedilyska i Zariččia na Lwowszczyźnie)" również dotyczył cech szczególnych situl.

O historii badań archeologicznych w rejonie Borszczowa, ogromnej liczbie znalezionych artefaktów, atrakcyjności historyczno-kulturowej Bilcza Złotego i konieczności dalszego badania stanowisk jaskiniowych na Tarnopolszczyźnie opowiadał M. Sochackij (Borszczów) w referacie „Badania archeologiczne w jaskini Werteba”.

J. Zajkovski (Mińsk) wystąpił z odczytem „Sakralne pasmo głównego europejskiego działu wód", w którym zilustrował tezę o skoncentrowaniu znacznej części obiektów sakralnych Europy wzdłuż głównego wododziału.

Referat „Pochodzenie nazwy Beskidów w świetle danych archeologii” zaprezentował M. Parczewski (Rzeszów). Autor przeanalizował w nim niemiecką, albańską i słowiańską etymologię tej nazwy.

Referat D. Pavliva i W. Petehyryča (Lwów) „Czy istniały wczesnośredniowieczne miasta niewspomniane w źródłach pisanych?” przerodził się w dyskusję, której uczestnicy - O. Sytnyk, M. Parczewski, J. Machnik - podkreślili znaczenie źródeł zarówno pisanych, jak i archeologicznych, oraz ich kompleksowej analizy w studiach nad historią osad, fortec i grodów.

A. Skyba (Kijów) w referacie „Matryce do produkcji części pasów z grodziska Zimne na Wołyniu" zaprezentował metalowe matryce, wykorzystywane do produkcji form glinianych, których z kolei używano do wykonania elementów pasa metodą odciskania. 
W referacie „Obiekty neolityczne ze stanowiska 1C w Gródku, pow. hrubieszowski (z badań Sławomira Jastrzębskiego 1983-1985)", wygłoszonym przez P. Zawiślaka (Rzeszów), omówiono obiekty kultur pucharów lejkowatych i lubelsko-wołyńskiej, odkryte podczas badań wykopaliskowych prowadzonych przez S. Jastrzębskiego w latach 1983-1985.

Odczyt „XVII-wieczne elementy pasmanteryjne stroju sarmackiego z kościoła Niepokalanego Poczęcia Najświętszej Marii Panny w Dubnie" zaprezentowała A. Dronżkowska (Toruń). Autorka podkreśliła, że dzięki mistrzowskiemu wykonaniu i wysokiej wartości ozdobnych elementów (guzików, sznurowań, pętelek, haftów, plecionek, frędzli itp.) polskie ubiory narodowe osiągały znaczną cenę.

S. Rassadin (Mińsk) w referacie „Znaleziska archeologiczne z monasteru Ławryszowskiego i jego najdawniejsze dzieje" przedstawił historię badań tego obiektu i odkryte znaleziska, które w większości pochodzą z XVI-XVIII w., najstarsze zaś są datowane na mezolit.

Poranna sesja sekcji „Archeologia pradziejowa” rozpoczęła się odczytem polsko-ukraińskiego zespołu badawczego w składzie: A. Bohucki, O. Sytnyk (Lwów), M. Łanczont (Lublin), T. Madejska (Warszawa), J. Kusiak (Lublin) i O. Tomeniuk (Lwów) pt. „Podsumowanie badań stratygraficznych i paleograficznych paleolitycznych stanowisk z grupy tarnopolskiej”. Badacze omówili kolejny etap interdyscyplinarnych badań terenowych, jakie od wielu sezonów wspólnie prowadzą polscy i ukraińscy naukowcy.

A. Zakościelna (Lublin), T. Chmielewski (Wrocław), M. Furmanek (Wrocław) i M. Mackiewicz scharakteryzowali „Fortyfikowane założenie osadniczo-funeralne kultury lubelsko-wołyńskiej w Mikulinie 8 na Wyżynie Zachodniowołyńskiej”. Autorzy zaprezentowali wyniki badań wykopaliskowych i wnioski dotyczące lokalnych, mieszkalno-bytowych aspektów ludzkiej działalności.

Odczyt W. Zachariewa (Chmelnicki) dotyczył rezultatów badań prowadzonych w ostatnich sezonach wykopaliskowych.

M. Vojtovyč (Lwów) przedstawił referat „Kultura ceramiki sznurowej na zachodzie Ukrainy: stanowiska typu Kawsko-Kołpeć”, w którym przeanalizował historię badań, rezultaty wykopalisk prowadzonych przez innych badaczy oraz scharakteryzował omawiany typ stanowisk.

W referacie „Co wywołało zmianę w ornamentyce trypolskiej na etapie BII?” T. Tkaczuk zilustrował związek zachodzący między zmianami klimatycznymi w regionie a przejściem od wielobarwnego do monochromatycznego zdobienia ceramiki.

P. Makarowicz (Poznań), S. Łysenko (Kijów), I. Koczkin (Ivano-Frankivs'k w odczycie „Wstępne wyniki badań cmentarzyska kurhanowego kultury komarowskiej w Bukivnej nad Dniestrem" przedstawili dotychczasowe rezultaty badań prowadzonych w ciągu ostatnich lat w ramach wspólnego polsko-ukraińskiego projektu badawczego na tej znanej nekropoli $\mathrm{z}$ epoki brązu.

T. Słobodian (Kijów) w referacie „Analiza antropologiczna pochówku ciałopalnego z kurhanu 2 na cmentarzysku Bukivna" przedstawiła wyniki badań pozostałości szkieletu kobiety, odkrytego w trakcie wykopalisk w 2012 r.

Wieczorna sesja sekcji „Archeologia pradziejowa”, która odbywała się pod kierownictwem W. Konopli i J. Onyščuka, rozpoczęła się odczytem H. Taras (Lublin) pt. „Nowe znaleziska broni o wschodniej proweniencji z epoki brązu w Polsce Środkowowschodniej”. Ogółem w tej części konferencji wysłuchano 13 referatów. 
W referacie O. Vojtiuk (Równe) „Badania budynków kultury miłogradzkiej we wsi Peresopnyca w obwodzie równeńskim" podsumowano wyniki ubiegłorocznych wykopalisk.

Wielkie stanowisko kultury czerniachowskiej, posiadające potężną bazę wytwórczą, osadę i infrastrukturę przedstawił V. Vojnarovski (Lwów) w referacie „Komarów nad Dniestrem: mity i rzeczywistość". Autor szczegółowo opowiedział o przeprowadzonych badaniach wykopaliskowych, scharakteryzował odkryte artefakty i podsumował swój wykład gruntownymi wnioskami dotyczącymi Komarowa, będącego dużą osadą - wsią kultury czerniachowskiej.

J. Baškatov (Kijów) w odczycie „O formowaniu się domostwa słowiańskiego (na podstawie materiałów pierwszej połowy I tys. n.e.)” opisał kulturowe i architektoniczne cechy budynków mieszkalnych Słowian.

Z. Krišovská i G. Lukáč (Livoča) przedstawili referat pt. „Staršie nálezy eneolitických kostených idolov a ozdôb z Dreveníka na Spiši (Slovensko)”. Referenci zaprezentowali rezultaty prac z ostatnich sezonów polowych, jak również historię badań archeologicznych prowadzonych na tym obiekcie.

Po kilku wygłoszonych referatach rozpoczęła się dyskusja, w której wzięli udział O. Sytnyk, V. Vojnarovski, N. Banbrivski i P. Makarowicz. Omawiano kwestię przynależności kulturowej stanowisk i interpretacji niektórych znalezisk.

Wiele referatów poświęcono stanowisku w Komarowie nad środkowym Dniestrem: O. Petrauskas (Kijów), T. Mylian (Lwów) - „Kwestia składu etnicznego mieszkańców późnorzymskiej faktorii produkcyjnej w Komarowie"; O. Petrauskas, D. Kozak (Kijów), T. Mylian, O. Osaulčuk (Lwów) - „Komarów - faktoria produkcyjna barbarzyńskiej Europy z późnego okresu wpływów rzymskich. Kwestia opracowania programu badań unikalnego stanowiska archeologicznego”; oraz odczyt S. Didenko (Kijów) - „Antyczny import ceramiczny z badań Komarowa - osady z późnego okresu wpływów rzymskich”.

W. Prokopiv (Lwów) w referacie „Znaleziska kościanych grzebieni na stanowiskach z pierwszej połowy I tys. n.e. w górnym dorzeczu Dniestra i Bohu” przeanalizował różnice w sposobach wytwarzania i zdobienia grzebieni wśród przedstawicieli różnych kultur: zubryckiej, lipickiej, wielbarskiej i czernichowskiej.

W referacie J. Onyščuka (Lwów) „Badania archeologiczne na osadzie z okresu wpływów rzymskich Malynyšče i na pograniczu wołyńsko-podolskim w 2012 r.” zaprezentowano pierwsze rezultaty najnowszych prac przeprowadzonych na stanowisku oraz odkryte artefakty - ceramikę kultury wysockiej, toczoną ceramikę z późnego okresu wpływów rzymskich i obiekty wziemne - jamy, ściany budowli itp.

O historii badań znanego stanowiska i pochodzących z niego znaleziskach - pochówku, ceramice, kościanym grzebieniu i brązowych sprzączkach - wygłosił referat O. Myłaševski (Kijów) w referacie „Kwestia chronologii cmentarzyska rakowieckiego kultury czerniachowskiej”.

W referacie B. Polit (Rzeszów) „Bransolety, kolczyki, pierścionki - metalowe ozdoby ciała pozyskane w trakcie badań wykopaliskowych przeprowadzonych w 2012 r. w Neyzats na Krymie" przedstawiona została klasyfikacja dużej kolekcji ozdób znalezionych w pochówkach sarmackich.

Posiedzenie sekcji „Archeologia pradziejowa” zakończyło się odczytem P. Męczyńskiego (Rzeszów) pt. „Prezentacja pradziejowych materiałów pozyskanych w trakcie sześciu 
sezonów badań prowadzonych na stanowisku nr 7 w miejscowości Dobryń Mały, gm. Zalesie". Autor opowiedział o wieloletnich badaniach mezolitycznego stanowiska o powierzchni 2 ha, na którym odkryto ponad 600 artefaktów z epoki kamienia.

Dwie sesje odbyły się w ramach sekcji „Archeologii średniowiecza i nowożytności”. Ogółem wysłuchano ponad 20 odczytów, poruszających wieloaspektową problematykę. W referatach prezentowano artefakty, uzasadniano koncepcje i wyrażano dyskusyjne przypuszczenia na temat specyfiki odrębnych kultur i warunków życia ludzi w średniowieczu. Duża część odczytów dotyczyła wyników badań archeologicznych, przeprowadzonych na Lwowszczyźnie. Były to między innymi referaty lwowskich archeologów, R. Myski, J. Pohoralskiego: „Badania grodzisk Pogórza Drohobyckiego w 2012 r.”, oraz tychże samych badaczy we współpracy z W. Liaską: „Nowe odkrycie grodziska w okolicy wsi Fijna na Roztoczu”; A. Hawinskiego i W. Opryska: „Historia badań stanowiska w pobliżu wsi Potelyča”; I. Frankiv: „Historia badań archeologicznych średniowiecznych stanowisk na Mikołajewszczyźnie”.

W wielu referatach przedstawiono rezultaty wykopalisk przeprowadzonych na terenie miast halickich. Były to między innymi odczyty o wynikach badań ratowniczych we Lwowie: J. Łukomski, O. Lazurko, M. Šnicar: „Badania na terenie dzielnicy żydowskiej we Lwowie”; N. Vojtovyč, M. Vojtovyč: „Badania ratunkowe na ul. Krakowskiej 6-12 we Lwowie w 2011 r.”. W referatach lwowskich badaczy prezentowane były i inne zabytki archeologiczne zachodniej Ukrainy - J. Knyš: „Graffiti Mścisława w cerkwi św. Pantalejmona w Haliczu”; O. Lazurko: „Lokalizacja obronnej linii Bełza w XIV-XVI w.”; R. Berest: „Średniowieczne świątynie w jaskiniach na Przedkarpaciu".

Kilka referatów dotyczyło wyników badań archeologicznych na Wołyniu - W. Savycki (Łuck): „Nowe znaleziska staroruskich emaliowanych krzyżyków na Wołyniu”; B. Pryščepa (Równe): „Nowe badania średniowiecznych osad wiejskich w dorzeczu Horynia”.

W trakcie sesji „Archeologia średniowiecza i nowożytności” wygłoszono również referaty przedstawiające wyniki badań w innych regionach Ukrainy, a także na Białorusi i w Polsce. Były to odczyty ukraińskich badaczy - M. Serhiejevej (Kijów): „O jeszcze jednym typie średniowiecznych kościanych guzików: pochodzenie, problem wytwórczości, funkcja"; S. Pyvovarova, W. Kaliničenki (Czerniowce): „Osada kultury rajkowieckiej w Ridkivcach (badania archeologiczne w 2010 r.)”; A. Vynohrodskiej (Kijów): „Średniowieczny kompleks ceramiczny z wykopalisk klasztoru Liadovskiego”; I. Prochnenko (Użhorod): „Problem atrybucji plemiennej pochówków koczowników z X w. n.e. w Przemyślu”.

W odczytach polskich kolegów zaprezentowane zostały różnorodne badania, od szczegółowych analiz różnych typów artefaktów do szerokopłaszczyznowych badań terenowych. Grupa referatów poświęcona była analizie wyrobów ceramicznych i szkła - M. Broszko (Jarosław): „Płytowe kafle heraldyczne z motywami religijnymi z Jarosławia”; D. Mazur (Kraków): „Zbiór kafli piecowych pozyskanych w trakcie archeologicznych badań sondażowych przeprowadzonych na ul. Ciemnej w Krakowie - wstępne wyniki analizy”; E. Nawrot (Rzeszów): „Nowożytna ceramika z Miechocina, pow. Tarnobrzeg”; S. Siemianowska (Wrocław): „Znaleziska wczesnośredniowiecznego szkła pochodzenia ruskiego z WrocławiaOstrowa Tumskiego i Opola-Ostrówka".

Wyniki badań archeologicznych na Białorusi przedstawili archeolodzy z Mińska M. Plavinski: „Nowe badania wykopaliskowe cmentarzyska kurhanowego Naury w rejonie Miadzelskim, obwód miński”; M. Klimov: „Archeologiczne dowody klimatycznych zmian 
w północnej Białorusi w drugiej połowie XIII i XIV w. (na podstawie badań stanowiska Łuczna-1)”; A. Baškov: „Wstępne rezultaty badań siedziby rodowej Dostojewskich w 2012 r.”.

Jubileuszowa, dziesiąta konferencja we Lwowie zakończyła się wycieczką na Tarnopolszczyznę, do jaskini Werteba. Badania w tym miejscu rozpoczęły się w latach 70. XVIII wieku. Pierwsze pisemne wzmianki o wynikach eksploracji tego obiektu zamieściło czasopismo „Pszczółka Krakowska” w 1820 r. W Wertebie pracowali znani archeolodzy polscy i ukraińscy: A. Kirkor, A. Sznajder, L. Sapieha, G. Ossowski, W. Demetrykiewicz, B. Janusz, J. Pasternak, O. Kandyba-Olżycz, I. Svešnikov, M. Sochacki. Zabytki archeologiczne z Bilcza Złotego znajdują się w Muzeum Archeologicznym w Krakowie i w muzeach na Ukrainie. Wizyta w „Naddniestrzańskich Pompejach”, możliwość obejrzenia sal i labiryntów Werteby, a także artefakty przechowywane w Borszczowskim Muzeum Krajoznawczym wywarły niezapomniane wrażenie na uczestnikach konferencji.

\section{Halyna Panakhyd}

Muzeum Historyczne we Lwowie, Lwów, Ukraine

Przemystaw Makarowicz

Instytut Prahistorii, Uniwersytet im. A. Mickiewicza

ul. Św. Marcin 78, 61-809 Poznań, Poland 